\title{
The Implementation of National Curriculum 2013 and International Baccalaureate (Study at Sampoerna Academy Medan) \\ DOI: https://doi.org/10.47175/rissj.v3i1.368
}

\section{| Mayolica Marsillam Toruan ${ }^{1}$ | Akrim $^{2}$ | Indra Prasetia ${ }^{3}$ |}

\author{
1,2,3 Master Program of Higher \\ Education Management, \\ Universitas Muhammadiyah \\ Sumatera Utara, Indonesia \\ ${ }^{1}$ mmtoruan@gmail.com \\ 2akrim@umsu.ac.id \\ 3indraprasetia@umsu.ac.id
}

\begin{abstract}
This study aims to determine the implementation of National Curriculum 2013 and the International Baccalaureate curriculum and to compare student learning outcomes, especially in the field of Indonesian language studies at Sampoerna Academy Medan. The results shows that there are differences in learning outcomes in the field of Indonesian language studies using National Curriculum 2013 and the International Baccalaureate. The difference in the level of ability of students in the field of Indonesian language studies is indicated by the average learning outcomes of Indonesian language studies with National Curriculum 2013 which is lower than the International Baccalaureate curriculum. The findings of this study indicate that the use of both National Curriculum 2013and the International Baccalaureate has an impact on student learning outcomes at Sampoerna Academy Medan. This difference is due to differences in assessment standards, learning activities, communication both oral and written as well as the values of cultural and character development of each curriculum applied in schools.

KEYWORDS

implementation; National Curriculum 2013; International Baccalaureate
\end{abstract}

\section{INTRODUCTION}

In an effort to improve the quality of human resources, the role of the curriculum in education is certainly one of the most important elements and components in the education system. In Indonesia today, the curriculum applied in the education system is the curriculum set by the Ministry of Education and Culture, namely National Curriculum 2013 (K-13) which is the development of the 2006 National Curriculum (KTSP). In National Curriculum 2013, it regulates the guidelines used to compile and develop learning tools including core competencies and basic competencies, where these two components can be developed in accordance with the demands of the needs of the education unit. Core competencies include four important values in the process of delivering knowledge which includes spiritual attitudes, social attitudes, knowledge and skills, where all four are designed as learning content that is integrated in achieving graduation competency standards. While basic competence contains a number of abilities that must be mastered by students in certain subjects which contain attitudes, knowledge and skills that are sourced from core competencies that must be mastered by students. In education units, the 2013 national curriculum is designed to provide opportunities for students to learn according to their interests, talents and abilities. In order for these three things to be served properly, National Curriculum 2013 provides students with the opportunity to choose subject groups based on students' interests so that they can add and develop their potential, insight, knowledge and knowledge in line with their future plans. 
While National Curriculum 2013 was deemed to be close enough to suit and meet the needs of educational standards for students, several groups of education units received different responses from the surrounding community, that changes to the existing curriculum in Indonesia have not been able to meet the needs of preparing future generations with a global perspective and have the ability to compete internationally. Therefore, slowly but surely a new phenomenon emerges where people show more interest in educational units that adopt international curricula. This is also supported by the magnitude of the flow of world globalization in various fields of life, including the field of work, where education units are expected to produce a generation of workers who are able to compete globally with the international community. Based on these factors, the existence of an educational unit with an international curriculum is increasingly attracting public attention. It is undeniable, nowadays many parents want their children to get an education not only in the academic field but also other skills and abilities that can adapt to the modernization of the times. To meet these needs, international schools are often used as a reference by implementing a global standard curriculum that is recognized as having a higher quality education system.

Subandi (2014); Najah \& Setiani (2020) explained that education units that apply an international curriculum are more directing students to have broad knowledge, dare to take risks, have great curiosity, have social concerns, are open and broad-minded, always prioritize thinking skills, have a sense of responsibility, able to develop plans and strategies to achieve goals, have the ability to balance physical, mental and spiritual abilities and be able to reflect knowledge. One of the government's efforts to respond to the public's enthusiasm for education with a quality international curriculum is contained in Law number 20 of 2003. The Government or Regional Government shall organize at least one education unit at all levels of education to be developed into an international standard education unit. Then through the regulation of The Ministry of Education and Culture Number 31 of 2014, the government regulates the implementation of education units with an international curriculum starting from licensing, implementing national and international curricula, implementing learning evaluations, teaching and educational staff to monitoring and evaluating the curriculum management system, including uniformity in the use of the word "international" which must change to a Cooperation Education Unit (SPK). Currently throughout Indonesia, there are 397 educational units with international curricula that have been nationally accredited. In the province of North Sumatra itself, especially in Medan, there are 13 SPKs that have been recognized by the government and have met the standards in accordance with eight educational standards in Indonesia. The thirteen SPK education units can be seen in the table below,

Table 1. Cooperation Education Units in the North Sumatra Region

\begin{tabular}{|l|l|l|}
\hline No & Name of Cooperation Education Unit & International Curriculum \\
\hline 1 & SD Medan Independent School (MIS) & International Baccalaureate \\
\hline 2 & SMP Medan Independent School (MIS) & International Baccalaureate \\
\hline 3 & SD Sampoerna Academy Medan (SAM) & Cambridge Curriculum \\
\hline 4 & SMP Sampoerna Academy Medan (SAM) & Cambridge Curriculum \\
\hline 5 & SMA Sampoerna Academy Medan (SAM) & $\begin{array}{l}\text { Cambridge Curriculum and } \\
\text { International Baccalaureate }\end{array}$ \\
\hline 6 & SD Prime One School (POS) & Cambridge Curriculum \\
\hline 7 & SMP Prime One School (POS) & Cambridge Curriculum \\
\hline 8 & SMA Prime One School (POS) & Cambridge Curriculum \\
\hline 9 & SD Singapore International School (SIS) & International Baccalaureate \\
\hline 10 & SMP Singapore International School (SIS) & International Baccalaureate \\
\hline
\end{tabular}




\begin{tabular}{|l|l|l|}
\hline 11 & SMA Chandra Kumala & Cambridge Curriculum \\
\hline 12 & SD Kingston & Cambridge Curriculum \\
\hline 13 & SMP Kingston & Cambridge Curriculum \\
\hline
\end{tabular}

According to Purnomo (2016), Rachmad (2017) the application of an international curriculum that is integrated with the national curriculum in the same education unit creates new challenges that are different from other educational units that only apply one curriculum, where teachers, students and curriculum management must be able to interact with each other. interact and be able to adapt to changes both in national and international scope. This is especially true for one of the SPKs in Medan, namely SMA SPK Sampoerna Academy Medan. Fika (2019) the process of interaction and adaptation to the two curricula that are carried out jointly requires students and teachers to be more active and creative in order to stay in tune with the educational goals of each curriculum and this has an impact on the learning system and student graduation standards. One of the interesting things in the curriculum management process at SPK is the existence of Indonesian language learning which has been known to exist only in the national curriculum, but it turns out that with the recognition of the achievements and performance of the Indonesian state in front of other countries in the world, Indonesian has become one of the most important languages in the world. language that is in demand by foreign education systems so that currently the Indonesian language subject has been included as one of the elective subjects in the international curriculum which is widely used in foreign countries, namely the International Baccalaureate curriculum, this is proof that Indonesian has been valued on a par with other languages. -Other international languages. It can be said that the implementation of a foreign curriculum that places Indonesian language learning in it has a different effect on student learning outcomes and the quality of student graduation standards. Therefore, this study aims to determine the implementation of the 2013 national curriculum and the International Baccarlaureate curriculum and their impact on learning Indonesian.

\section{RESEARCH METHODS}

This research is a comparative quantitative study, which compares the results of two treatments in different groups. Sugiono (2013); Moeloeng (2006) that comparative research is directed to find out whether between two or more than two groups there are differences in the aspects or variables studied. According to Sudijono (2009), comparative research is essentially research that seeks to find similarities and differences about objects, people, work procedures, ideas, criticism of people or groups, of ideas or work procedures. It can also be used to compare common views and changes in views of people, groups or countries towards cases, events or ideas. In this study, there was no control variable, nor manipulation or treatment by researchers, namely comparing the implementation of the 2013 national curriculum and the international Baccalaureate curriculum and its impact on Indonesian language learning outcomes at Sampoerna Academy Medan. The research was conducted naturally, the researcher collected data using documentation and observation studies. The collected data were analyzed statistically to find differences between the variables studied.

\section{RESULTS AND DISCUSSION}

\section{Impact of Curriculum on Student Character}

Samporna Academy Medan was established at the beginning of the 2007/2008 academic year under the name Singapore Piaget Academy and was nationally accredited in 2011 
with a national accreditation score of A. In the 2015/2016 academic year, the Singapore Piaget Academy school changed its name to Sampoerna Academy Medan while still implementing the international curriculum. in the learning system. The campus in Medan is one of five Sampoerna Academy campuses spread across Indonesia. With a student population of almost 1000 students from primary to upper education levels, Sampoerna Academy Medan has produced many students with proud achievements on the international stage, because the Sampoerna Academy Medan Cooperation Education Unit (SPK) has implemented two international curricula, one of which is the International Baccalaureate. SPK Sampoerna Academy Medan implements the 2013 national curriculum and the International Baccalaureatedi curriculum, so that the teaching and learning process in Indonesian subjects at school has its own obstacles, because Indonesian is a subject that is still difficult to be absorbed by students in this school considering that most of them use English both inside and outside of school. For schools that implement two learning curricula in one container, of course, it will have an impact on their students which will be seen in the learning process and learning outcomes. SPK Sampoerna Academy Medan is one of the educational units that does this for students in class XI and XII where at each level students are divided into two groups of learning programs, namely groups of students who use the Cambridge curriculum and the 2013 national curriculum in Indonesian subjects, Religious Education. and PPKn and groups of students who use the IB curriculum and the 2013 national curriculum in the subjects of Religious Education and PPKn. Especially for groups of students who use the IB curriculum, the Indonesian subjects studied are Indonesian subjects contained in the IB curriculum. The International Baccalaureate Curriculum also stipulates several requirements for students taking this program group, where each student is required to study three core subjects and six subjects from each subject group.

In particular, the aim of the IB curriculum is to teach students to explore what is to be learned, ask challenging and thoughtful questions, develop a sense of identity and culture, develop the ability to communicate with people from different countries and cultures. Thus, these two curricula have differences in the preparation of curriculum governance, especially Indonesian subjects. While in the 2013 national curriculum, the system taught will not be too difficult in its implementation, because generally in the 2013 national curriculum the topics taught are shorter but detailed, so that analytical skills are not really needed in conveying the material. The division of basic competence 1 and basic competence 2 is more about determining spiritual and social attitudes, while basic competence 3 and basic competence 4 are determining attitudes and character. Graduation standards in the 2013 national curriculum are determined through the cumulative results of student scores.

Another impact on student learning, where in the 2013 national curriculum students are more focused on the topic of discussion given by the teacher in accordance with the learning implementation plan and follow the discussion that has been structured in the textbook, with a pattern that has been arranged standardly both in the book and lesson plans, more students follow the flow and see the examples that have been given. While in the International Baccalauratate curriculum, the teacher places more emphasis on students' abilities to analyze, develop observational material and draw an understanding and conclusion from the results of their respective observations. So that each student has the freedom to give their own assessment of a problem and develop their creative ideas to take solutions to the problem. The positive and negative values that are the result of the 2013 national curriculum and the International Baccalaureate curriculum depend on the setting of the goals of each student, where this is the starting point of all processes that will be 
carried out in order to achieve the goals set for each curriculum, so that in Finally, every curriculum implementation in every learning program has the same ultimate goal, namely to produce students as students of all time who are ready to face all global challenges in the future.

\section{Analysis and results of Soft-skills Training}

The implementation of the curriculum in a school certainly has an impact on student learning outcomes. In this study, the research data collected to measure the impact comes from the learning outcomes of SPK Sampoerna Academy Medan students in Indonesian lessons with the 2013 curriculum and the International Baccalaureate curriculum. Data on student learning outcomes comes from data on Indonesian language learning outcomes for the 2013 curriculum and the International Baccalaureate. The results of data analysis from each experimental class are presented in Table 1.

Table 1. Average Student's Indonesian Language Learning Outcomes

\begin{tabular}{|l|c|c|}
\hline \multicolumn{1}{|c|}{ Score } & National Curriculum 2013 & IB \\
\hline Average & 79,70 & 84,83 \\
\hline Category & Good & Good \\
\hline
\end{tabular}

Furthermore, data analysis is to test the normality of research data as shown in Table 2 below:

Table 2. Data Normality Test

\begin{tabular}{|l|c|c|}
\hline Parameter & National Curriculum 2013 & IB \\
\hline The number of students & 33 & 18 \\
\hline Average & 79,70 & 84,83 \\
\hline The highest score & 97 & 100 \\
\hline Lowest & 65 & 66 \\
\hline Asymp.sig (2-tailed) & 0,200 & 0,200 \\
\hline
\end{tabular}

Based on Table 2 above, it can be seen that the two data are normally distributed, where Asymp.sig (2-tailed) $>0.05$. It can be said that the data can be continued for research analysis. Next is to determine the analysis of differences in the two types of data and see the differences in Indonesian language learning outcomes for students who use the 2013 national curriculum and the International Baccalaureate. The results of data analysis are described in Table 3 below:

Table 3. ANOVA Test (Difference Test)

\begin{tabular}{|l|c|}
\hline \multicolumn{1}{|c|}{ Perameter } & National Curriculum 2013-IB \\
\hline $\mathrm{F}$ & 0,364 \\
\hline Sig & 0,549 \\
\hline $\mathrm{t}$ & 1,74 \\
\hline $\mathrm{df}$ & 49 \\
\hline Sig (2-tailed) & 0,00 \\
\hline
\end{tabular}

Based on Table 3 above, the significant value in the $F$ test is 0.364 greater than 0.05 , then $\mathrm{H} 0$ is accepted and it can be concluded that the variance of data groups 1 and 2 are the same. With this the use of $t$ test using Equal Variances Assumed. After knowing that the variance of the two data is the same, then a t-test is performed. The calculated value of $t$ Equal Variances Assumed in the table above is 1.74 while the value of the table is 1.69. The calculated value of $t>t$ table $(1.74>1.69)$ and the significance $(0.00<0.05)$ then Ho is rejected. Based on the results of these tests, it can be concluded that "There is a difference 
in the average student learning outcomes in Indonesian lessons with the 2013 curriculum and the International Baccalaureate curriculum" which means that the use of both the 2013 curriculum and the International Baccalaureate has an impact on student learning outcomes in Language subjects. Indonesia. And the impact of student development in Indonesian subjects is not only through assessment standards but also through oral and written communication activities.

The difference in learning outcomes in the application of the two curricula clearly shows that the IB curriculum applies several assessment standards to its students, the first is the internal assessment standard at the standard level consisting of individual oral assessments where this assessment focuses on the competence of students' productive and interactive skills through oral presentations and follow-up discussions with teachers based on at least one topic in the syllabus. The second internal assessment standard is at a high level which consists of individual oral assessments that focus on the competence of students' productive and interactive skills through oral presentations and follow-up discussions with teachers based on one or more of the five deepest topics in the syllabus. The final assessment standard contained in the IB curriculum is in the implementation of the exam at the end of the second year of the school year where its implementation is carried out in schools and is directly supervised by the nearest IB representative.

Sukmadinata (2005:30); Rivai and Murni (2000) suggest three basic elements of the curriculum, namely actors, artifacts, and implementation. Actors are people who are involved in implementing the curriculum, in this case at SPK Sampoerna Academy Medan, the teachers and students are the implementers of the curriculum. Subandi (2014) artifact is the content and design of the curriculum, in which actors develop the 2013 national curriculum and the IB curriculum into the implementation plan of classroom learning. Implementation is a process of interaction between actors involving artifacts so as to produce an impact on students which is produced to show a difference from the implementation of Indonesian language learning in other educational units. Curriculum study according to Frymier includes three steps, namely planning, implementation, and evaluation. At the SPK Sampoerna Academy Medan education unit, the two curricula are implemented according to the rules for their respective preparation and their development is aligned with the situation and condition of students and schools.

With the background that the majority of students at SPK Sampoerna Academy Medan are ethnic Chinese who use Hokkien as their first and everyday language and are supported by the implementation of an international curriculum with English as the language of instruction, the use of Indonesian as a communication tool becomes the last choice for students. students from their childhood. This is a challenge for educators to be able to hone and improve students' skills in Indonesian, both through the 2013 national curriculum and the International Baccalaureate curriculum. The results of this study prove that both with the 2013 national curriculum and the International Baccalaureate curriculum, learning Indonesian at SPK Sampoerna Academy Medan has an impact on students being able to communicate using Indonesian better.

\section{CONCLUSION}

Based on the results of the research and a description of the discussion on the implementation of the 2013 national curriculum and the International Baccalaurreate curriculum in Indonesian language learning at the SPK Sampoerna Academy Medan education unit, the advantages of each curriculum have different impacts on the development and communication skills of students in using Indonesian both orally. as well as writing. The second use of the 2013 curriculum and the International Baccalaureate has 
a significant impact on student learning outcomes in Indonesian subjects, this impact can be seen from learning outcomes, cultural development and character values obtained by students. In addition, the results of implementing the Baccalaureate curriculum are better due to the existence of high standards of assessment for students, including internal assessment standards on individual oral abilities, where this assessment focuses on the competence of productive and interactive skills of students through oral presentations and continued discussions with teachers, at least one topic in the syllabus. The second internal assessment standard is at a high level which consists of individual oral assessments that focus on the competence of students' productive and interactive skills through oral presentations, follow-up discussions with teachers based on one or more of the five topics in the syllabus. The final assessment standard in the Baccalaureate curriculum is found in the implementation of the exam at the end of the second year where its implementation is carried out at school and is directly supervised by the nearest Baccalaureate representative.

\section{REFERENCES}

Anselm, Strauss dan Juliet. Corbin. (1997). Dasar-Dasar Penelitian Kualitatif Prosedur, Tehnik, dan Teori Surabaya: Bina Ilmu Ofset

Fika, Trisnawani. (2019). Studi Komparatif Tentang Tata Kelola Implementasi Kurikulum Nasional 2013 Dan Kurikulum International Baccalaureate (Kajian Pada Mata Pelajaran Bahasa Inggris Di SD Nurul Aulia dan Bandung Independent School)

Kementrian Pendidikan dan Kebudayaan. Dokumen Kurikulum Nasional. (2013). Jakarta: Kemendikbud

Lexy, Moleong. (2006). Metodologi Penelitian Kualitatif. Bandung: PT Remaja Rosdakarya Miles, MB \& Huberman AM. (1992), Analisis Data Kualitatif. Jakarta: Universitas Indonesia Muhadjir, Noeng. (2000). Metode Penelitian Kualitatif. Jogja: Rake Sarasin

Najah, S.Z, \& Setiani, N. (2020). Implementation of Cambridge International Curriculum in Biology Learning and its Impact on Critical Thinking Skills of Students in Semesta Senior High School. Journal of Biology Education, Vol 9 No 1, 64-75.

Prasetia, I dan Irawan, E. Manajemen Pengembangan Kurikulum (Studi Di Lab Site Balai Pengembangan PAUD dan Pendidikan Masyarakat Sumatera Utara), Jurnal Manajemen Pendidikan Dasar Menengah dan Tinggi, Vol 1 No 1, 2020

Purnomo. CH. (2016). Manajemen Pembelajaran Kurikulum International Baccalaureate Primary Years Programme Di SD Ciputra Surabaya

Putra, Nusa. (2012). Metode Penelitian Kualitatif Pendidikan Jakarta: Raja Grafindo Persada

Rusman. (2011). Model-Model Pembelajaran. Jakarta: Rajagrafindo Persada

Saryono. (2010). Metode Penelitian Kualitatif. Bandung: PT Alfabeta

Subandi. (1014). Indonesian Curriculum Development: Meaning-Based Curriculum and Competency-Based Curriculum in the Context of Teaching English Subject. International Conference on Education and Language (ICEL), Vol 1 (2014)

Subandi (2014) Pengembangan Kurikulum nasional 2013 (Studi Analitis Dan Subtantif Kebijakan Kurikulum Nasional). Yogyakarta: Pustaka Pelajar

Sugiyono. (2006). Metode Penelitian Pendidikan: Pendekatan Kuantitatif dan Kualitatif dan R\&B, Bandung: Alfabeta

Sukmadinata dan Syaodih. (2005). Landasan Psikologi Proses Pendidikan. Bandung: Remaja Rosda Karya

Rachmad, Priyadi. (2017). Manajemen Pembelajaran International Baccalaureate Primary Years Programs In Surabaya Intercultural School 